\title{
Eagle syndrome: case report
}

\section{Eagle sendromu: Olgu sunumu}

\author{
Irem Fatma ULUDAĞ,' Levent ÖCEK,' Yaşar ZORLU,' Burhanettin ULUDAĞ²
}

\begin{abstract}
Summary
Eagle syndrome is an aggregate of symptoms caused by an elongated styloid process, most frequently resulting in headache, facial pain, dysphagia and sensation of foreign body in throat. The proper diagnosis is not difficult with clinical history, physical examination and radiographic assessment if there is a sufficient degree of suspicion. The treatment is very effective. We report here a typical case of Eagle syndrome which was misdiagnosed as trigeminal neuralgia for many years and was treated with carbamazepine. We aim to point the place of Eagle syndrome in the differential diagnosis of facial pain. We also reemphasize the usefulness of the three-dimensional computed tomography in the diagnosis of Eagle syndrome. Even though Eagle syndrome is a rare condition, in cases of facial pain refractory to treatment or unexplained complaints of the head and neck region, it should be considered in the differential diagnosis as it has therapeutic consequences.
\end{abstract}

Key words: Cervicofacial pain; Eagle syndrome; facial pain; trigeminal neuralgia.

\section{Özet}

Eagle sendromu, elonge stiloid çıkıntının neden olduğu belirtiler topluluğudur. Eagle sendromunda başağrısı, yüz ağrısı, disfaji ve boğazda yabancı cisim varlğ̆ı hissi sık görülür. Öykü, fizik muayene ve görüntüleme bulgularılla kolayca tanı konulabilir. Cerrabi tedavi etkindir. Olgu yüz ă̆rısı şikayeti nedeniyle trigeminal nevralji tanısı almış ve uzun yıllardır karbamazepin kullanmaktadır. Düz kafa grafisi ve boyun bölgesinin üç boyutlu bilgisayarlı tomografisi tipik Eagle sendromu bulguların göstermektedir. Bu olgu ile yüz ağrisı ayırıı tanısinda Eagle sendromunun yerine dikkat çekilmiş ve Eagle sendromu tanısında üç boyutlu bilgisayarlı tomografinin kullanımı üzerinde durulmuştur. Eagle sendromu, nadir bir durum olarak düşünülse de, özellikle cerrabi tedaviye iyi yanıtı nedeniyle baş ve boyun bölgesiyle ilgili açıklanamayan şikayetleri olan, tıbbi tedaviye dirençli hastalarda akla gelmelidir.

Anahtar sözcükler: Servikofasiyal ağrl; Eagle sendromu; yüz ağrısl; trigeminal nevralji.

\section{Introduction}

In 1937, the association of cervicofacial pain and elongated styloid process with calcification or ossification of the stylohyoid ligament was described by Eagle in a pair of case reports. ${ }^{[1]}$ Eagle syndrome is characterized by facial and neck pain but may also manifest itself in a variety of symptoms such as dysphagia, tinnitus, otalgia, syncope and focal cerebral symptoms. The etiology and the pathophysiology of the syndrome are poorly understood. The clinical di- agnosis is difficult and radiologic confirmation is required. The surgical treatment is highly effective. ${ }^{[1-5]}$

Eagle syndrome is a rare and unusual cause of head and neck pain. It can be confused with oropharyngeal and maxillofacial disorders and particularly with cranial neuralgias but with appropriate clinical history and radiography, Eagle syndrome can easily be identified and treated.

\footnotetext{
'Department of Neurology, Izmir Tepecik Training and Research Hospital, Izmir;

${ }^{2}$ Department of Neurology, Ege University Faculty of Medicine, Izmir, Turkey

'İzmir Tepecik Eğitim ve Araştırma Hastanesi, Nöroloji Kliniği, İzmir;

Ege Üniversitesi Tıp Fakültesi Hastanesi, Nöroloji Anabilim Dalı, İzmir

Submitted (Başvuru tarihi) 04.05.2012 Accepted after revision (Düzeltme sonrası kabul tarihi) 15.06.2012

Correspondence (İletişim): İrem Fatma Uludağ, M.D. İzmir Tepecik Eğitim ve Araştırma Hastanesi, Nöroloji Kliniği, İzmir, Turkey.

Tel: +90 - 232 - 4696969 e-mail (e-posta): fatmairem@yahoo.com
} 


\section{Case Report}

The patient was a 70-year-old man with a 27 -year history of constant right facial pain radiating into the anterior auricular area. Mouth opening and the anteflexion of the head precipitated episodes of more severe pain during several seconds to minutes. The pain spread also to the left side of the face for the last 6-7 months. He was diagnosed with trigeminal neuralgia at the beginning of the disease and was treated unsuccessfully with carbamazepine since then. His history was uneventful for any significant craniofacial trauma or surgery. Medical history was noncontributory. Physical examination revealed an exacerbation of the pain by palpation of the tonsillar fossa bilaterally. Neurological examination as well as brain and cervical magnetic resonance imaging and angiography were unremarkable. Radiographic examination demonstrated styloid processes extending down into the area of the tonsillar fossa bilaterally (Fig. 1a). Computed tomography (CT) of the neck with three-dimensional reconstruction showed elongation of the styloid processes that were $5.1 \mathrm{~cm}$ long on both sides (Fig. 1b-d). The findings were compatible with Eagle syndrome and the patient underwent surgical removal of the elongated styloid process.

\section{Discussion}

The styloid process and the stylohyoid ligament are derived from Reichert's cartilage, which arises from the second pharyngeal arch. Reichert's cartilage is divided into tympano-hyal, stylo-hyal, cerato-hyal and hypo-hyal parts. The ossification of the stylo-hyal part and its fusion with the tympano-hyal part causes a long styloid process. Different theories such as post-traumatic reactive hyperplasia and metaplasia, anatomical variations, postmenopausal endocrine dysfunction and genetical transmission are proposed to explain this abnormal ossification but the exact cause of the Eagle syndrome is still not clear. ${ }^{[6,7]}$

The normal length of the styloid process is estimated to be $2.5 \mathrm{~cm}$ by Eagle. ${ }^{[8]}$ In further research, the average sizes varying from 2.6 to $4 \mathrm{~cm}$ are reported. Generally, if the length of the styloid process is more than $3 \mathrm{~cm}$, it is considered to be elongated. ${ }^{[9-10]}$ The incidence of styloid process elongation is controversial. Eagle reported an incidence rate of 4\%. Many authors reported a wide range of incidence rates, lower or much higher than Eagle's, reaching a frequency as high as $28 \%$. The incidence of the stylalgia is much lower than the incidence of elongated styloid process; only a small percentage (between $4 \%$ and $10.3 \%$ ) of the patients with elongated styloid process are thought to actually be symptomatic. Styloid process elongation is usually bilateral, however, in most cases, the symptoms are typically unilateral and bilateral symptoms are quite rare. ${ }^{[1-13]}$

Clinically two groups with different etiologies are identified. First or the classic type Eagle syndrome is typically seen in patients after tonsillectomy or minor trauma. The pain is often felt on the angle of the mandible and it may radiate to the ipsilateral ear. The palpation of the ipsilateral tonsillar fossa may exacerbate the patient's symptoms. The elongated styloid process can be palpated in the fossa. Frequent symptoms other than facial pain are dysphagia, tinnitus, the sensation of a foreign body in the throat and otalgia. The impingement of the cranial nerves V, VII, IX, X which pass in close proximity to the styloid process is thought to be the cause of the symptoms. The second type is attributed to impingement of the internal or external carotid artery by the styloid process deviating slightly from its normal direction. Eye pain, pain in the face below the eyes or parietal headache may be seen. Palpation of
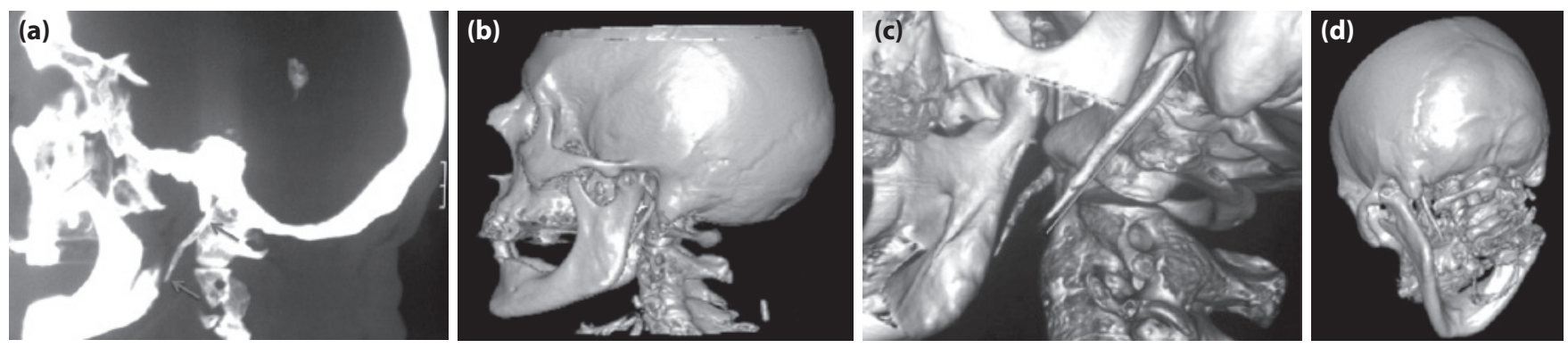

Figure 1. (a) Lateral view plain radiograph of the skull shows elongated styloid process extending from the base of the hyoid bone (arrows). Lateral $(\mathbf{b}, \mathbf{c})$ and oblique (d) three-dimensional computed tomography images show elongated styloid processes on both sides. The lengths of the styloid processes are $5.1 \mathrm{~cm}$ on both sides (c). 
the artery may be painful because of the stimulation of the sympathetic nerve plexus accompanying the artery. Interruption of blood flow within the affected artery may cause syncope and focal cerebral symptoms including aphasia, blindness and weakness. ${ }^{[1-5,8]}$

The diagnosis is based on the clinical signs, digital palpation of the styloid process in the tonsillar fossa, radiological findings and lidocaine infiltration test. [14] The lidocaine infiltration test result is considered positive for Eagle syndrome if the patient's symptoms subside with the administration of $1 \mathrm{ml} 2 \%$ lidocaine to the area of the styloid process in the tonsillar fossa. [15] Three-dimensional CT is considered to be the gold standard for the diagnosis of Eagle syndrome. It allows the accurate measurement of the length of the styloid process, better depiction of the anatomy of the surrounding structures and visualization of the exact spatial orientation of the styloid processes. ${ }^{[16,17]}$

The differential diagnosis includes migraine and other headaches, trigeminal, glossopharyngeal and other cranial neuralgias, ear nose and throat diseases such as tonsillitis and otitis, degenerative diseases causing neck pain, psychosomatic diseases and inflammatory and neoplastic processes in the oropharyngeal area. ${ }^{[14]}$

Conservative treatment options are nonsteroidal anti-inflammatory medications, the injection of steroids and long-lasting anesthetics into the tonsillar fossa. Surgical excision of the elongated styloid process with transcervical or transpharyngeal approaches is often successful. ${ }^{[18]}$

Our case was presented with a long history of cervicofacial pain centered on the angle of the mandible. The pain was referring to the ipsilateral ear and was exacerbating with mouth opening and sudden head movements. Hypersensitivity in the region of tonsillar fossa was observed on palpation. Three-dimensional CT of the neck demonstrated bilateral elongated styloid processes consistent with Eagle syndrome. Although this classic form of Eagle syndrome is typically seen in patients after tonsillectomy, our patient did not present with any history of pharyngeal surgery. Bilateral elongation of the styloid processes despite unilateral symptoms is very frequent in cases of Eagle syndrome, but interestingly, in our patient's case, symptoms were observed only on one side for many years and then occured on both sides within the last 6 to 7 months.
In our patient, the mandibular pain triggered with jaw movements led to the misdiagnosis of trigeminal neuralgia and the patient could not be treated properly for 27 years. Because of the wide range of clinical manifestations, Eagle syndrome may be confused with trigeminal neuralgia, like in our case, as well as with most disorders of the head and neck. It is a rare condition but is probably more common than generally considered and it should be kept in mind in the management of refractory cervicofacial pain.

\section{References}

1. Eagle WW. Elongated styloid processes: report of two cases. Arch Otolaryngol 1937;47:584-87.

2. Bafaqeeh SA. Eagle syndrome: classic and carotid artery types. J Otolaryngol 2000;29(2):88-94.

3. Zuber M, Meder JF, Mas JL. Carotid artery dissection due to elongated styloid process. Neurology 1999;53(8):1886-7.

4. Chuang WC, Short JH, McKinney AM, Anker L, Knoll B, McKinney ZJ. Reversible left hemispheric ischemia secondary to carotid compression in Eagle syndrome: surgical and CT angiographic correlation. AJNR Am J Neuroradiol 2007;28:143-5.

5. Dao A, Karnezis S, Lane JS 3rd, Fujitani RM, Saremi F. Eagle syndrome presenting with external carotid artery pseudoaneurysm. Emerg Radiol 2011;18(3):263-5. [CrossRef]

6. Steinmann EP. A new light on the pathogenesis of the styloid syndrome. Arch Otolaryngol 1970;91(2):171-4. [CrossRef]

7. Lorman JG, Biggs JR. The Eagle syndrome. AJR Am J Roentgenol 1983;140(5):881-2. [CrossRef]

8. EAGLE WW. Symptomatic elongated styloid process; report of two cases of styloid process-carotid artery syndrome with operation. Arch Otolaryngol 1949;49(5):490-503. [CrossRef]

9. Gözil R, Yener N, Calgüner E, Araç $M$, Tunç E, Bahcelioğlu M. Morphological characteristics of styloid process evaluated by computerized axial tomography. Ann Anat 2001;183(6):527-35.

10. Yavuz H, Caylakli F, Yildirim T, Ozluoglu LN. Angulation of the styloid process in Eagle's syndrome. Eur Arch Otorhinolaryngol 2008;265(11):1393-6. [CrossRef]

11. Correll RW, Jensen JL, Taylor JB, Rhyne RR. Mineralization of the stylohyoid-stylomandibular ligament complex. A radiographic incidence study. Oral Surg Oral Med Oral Pathol 1979;48(4):286-91. [CrossRef]

12. EAGLE WW. Elongated styloid process; symptoms and treatment. AMA Arch Otolaryngol 1958;67(2):172-6. [CrossRef]

13. Kaufman SM, Elzay RP, Irish EF. Styloid process variation. Radiologic and clinical study. Arch Otolaryngol 1970;91(5):460-3.

14. Piagkou M, Anagnostopoulou S, Kouladouros K, Piagkos G. Eagle's syndrome: a review of the literature. Clin Anat 2009;22(5):545-58. [CrossRef]

15. Prasad KC, Kamath MP, Reddy KJ, Raju K, Agarwal S. Elongated styloid process (Eagle's syndrome): a clinical study. J Oral Maxillofac Surg 2002;60(2):171-5. [CrossRef]

16. Savranlar A, Uzun L, Uğur MB, Ozer T. Three-dimensional CT of Eagle's syndrome. Diagn Interv Radiol 2005;11(4):206-9.

17. Nayak DR, Pujary K, Aggarwal M, Punnoose SE, Chaly VA. Role of three-dimensional computed tomography reconstruction in the management of elongated styloid process: a preliminary study. J Laryngol Otol 2007;121(4):349-53. [CrossRef]

18. Baugh RF, Stocks RM. Eagle's syndrome: a reappraisal. Ear Nose Throat J 1993;72(5):341-4. 